\title{
26 Research Soure \\ Practice and perception of Bangladeshi adults toward COVID-19: a cross-sectional study
}

\section{Md. Abdul Wadood}

Medical Centre, University of Rajshahi, Rajshahi- 6205, Bangladesh

\section{Lai Lee Lee}

Department of Orthopaedic Surgery (NOCERAL), Faculty of Medicine, University of Malaya, 50603 Kuala Lumpur, Malaysia

\section{Md. Monimul Huq}

Health Research Group, Department of Statistics, University of Rajshahi, Rajshahi-6205, Bangladesh

\section{ASMA Mamun}

Health Research Group, Department of Statistics, University of Rajshahi, Rajshahi-6205, Bangladesh

\section{Suhaili Mohd}

Department of Orthopaedic Surgery (NOCERAL), Faculty of Medicine, University of Malaya, 50603 Kuala Lumpur, Malaysia

\section{Md. Golam Hossain ( $\square$ hossain95@yahoo.com )}

Health Research Group, Department of Statistics, University of Rajshahi, Rajshahi-6205, Bangladesh

\section{Research Article}

Keywords: COVID-19, Practice, Perception, Bangladeshi adults, Logistic regression

Posted Date: May 15th, 2020

DOI: https://doi.org/10.21203/rs.3.rs-29364/v1

License: (c) (1) This work is licensed under a Creative Commons Attribution 4.0 International License. Read Full License 


\section{Abstract}

Background: The coronavirus disease 2019 (COVID-19) has continued to spread across the world with increasing number of confirmed cases and death. Preventive measures have still been the only way of slowing down the transmission and prevention of the deadly disease. Practice of preventive guidelines and perception about the disease is important in this regard. We aimed to study on practice to prevent and perception toward COVID-19 among Bangladeshi adults during the rapid rise of the outbreak.

Methods: For this cross-sectional study, we conducted an online survey to collect data from 320 Bangladeshi adults during the period of 10-20 April, 2020 with a self-developed questionnaire. For measuring their level of practice, a general question was asked to participants, "Are you properly following the guidelines recommended by WHO to avoid COVID-19? Four type of perceptions; (i) seriousness, (ii) susceptibility, (iii) efficacy, and (iv) carry out the measures of the disease were considered for measuring risk of perception. Frequency distribution, Chi-square $\left(\chi^{2}\right)$ test and binary logistic regression model were utilized in this study.

Results: More than $71 \%$ of participants had good practice of always following the guidelines of the World Health Organization to prevent COVID-19. Logistic regression model demonstrated that people living in urban area $(p<0.01)$, high education $(p<0.01)$, rich $(p<0.01)$ and joint family $(p<0.01)$ had the most contributions to good practice. The average risk perception among participants was $3.05 \pm 0.75$ (median, 3.00 ) (95\% $\mathrm{Cl}$ of mean: $2.96-3.13)$. More than $27 \%$ participants showed high risk perceptions. It was found that males $(p<0.05)$, high educated $(p<0.05)$, rich $(p<0.01)$, service holders $(0.05)$ and younger adults $(p<0.05)$ had higher odds of high risk perception.

Conclusions: The good practice of preventive guidelines and risk perception toward COVID-19 among Bangladeshi adults were satisfactory but not of the expected level. High socioeconomic status and education were significantly correlated with appropriate practice and perception during the peak time of the COVID-19 pandemic. Government should take step to increase the level of practice to avoid and perception toward COVID-19 among Bangladeshi people during the pandemic.

\section{Background}

The coronavirus disease 2019 (COVID-19) is a highly infectious respiratory disease with main clinical symptoms of sore throat, fever, dry cough, difficulty breathing, myalgia and fatigue [1]. Its causative agent, 2019 Novel Coronavirus (2019nCoV), is a newly emerging zoonotic coronavirus which transmits from animal to human and human to human by the droplet and feco-oral route, and direct contact and has an incubation period of 2 to 14 days [2, 3]. Most of the cases of COVID-19 need no special treatment but a little number of the disease may turn severe, even fatal, especially in people of older age and with comorbid health problems such as chronic respiratory diseases, diabetes, cardiovascular diseases, high blood pressure and cancer $[1,4]$. 
The COVID-19 outbreak occurred first in Wuhan city, the capital of Hubei province in China in December 2019 [5]. Since then, it has continued to spread with an increase in the number of confirmed cases and death worldwide. The outbreak has appeared as the biggest disaster in the 22nd century. The World Health Organization (WHO) has declared it as a Public Health Emergency of International Concern on January 30, 2020 [6] and pandemic on 11 March 2020 [7]. The situation is deteriorating daily and as of May 3, 2020, a total of 3,861,697 confirmed cases and 269,867 deaths were recorded in 210 countries and territories [8]. The battle against COVID-19 is still ongoing everywhere all over the world.

A poor understanding of the transmission, control and preventive measures of the disease may cause easy and rapid spread and delayed treatment of it. Till now, no vaccine or specific treatment is available for the control and management of the disease [1]. The most effective measure of controlling the spread of the virus is to protect oneself from being exposed to COVID-19. People's knowledge, attitude, perception and practice regarding the disease are the keys to ensuring success in the battle against the deadly disease. WHO has already prescribed some general guidelines for all sections of people to remain protected from COVID-19: (i) being well-informed about the mode of transmission of the virus and the signs and symptoms of the disease it causes; (ii) washing hands frequently with soap for at least 20 seconds or disinfecting hands by sanitizers; (iii) avoiding touching of the face, nose, mouth, and eyes without washing or sanitizing hands properly; (iv) maintaining a social distance of at least one meter from one another; (v) staying home; (vi) avoiding crowds and gatherings; (vi) practicing respiratory etiquettes such as wearing masks, using handkerchiefs, tissue papers or flexed elbows to cover nose and mouth during coughing and sneezing, and so on [1]. In 2003, SARS outbreak showed that knowledge and attitude toward infectious diseases are associated with panic and emotional breakdown among the population, which further complicated the control and prevention of the infection $[9,10]$.

In Bangladesh, the number of cases of COVID-19 and death has continued to increase since the identification of its first confirmed case on March 8, 2020. As of May 8, 2020, a total of 13,134 confirmed cases and 206 deaths were recorded in the country [11]. Like other countries in the world, Bangladesh is also trying to expand its controlling measures by imposing countrywide lockdown and urging people to maintain the preventive guidelines of WHO. Extensive campaign in print, electronic and social media, as well as by government and non-government organizations among people in the localities has supposedly increased the knowledge level of the general population about the causation, spread, control and prevention COVID-19. But, according to media reports, the prescribed guidelines are not being followed well. It is needed to investigate the practice to avoid and perception toward COVID-19 among Bangladeshi adults. To the best of our knowledge, only two published articles are available now on this issue. One study has assessed the knowledge, attitude, practice and perception toward COVID-19 among students in Rajshahi University, Bangladesh [12]. Another article studied knowledge and perception of Bangladeshi people towards COVID-19 [13]. Both the studies were conducted in the early stage of the COVID-19 outbreak in Bangladesh.

Therefore, we aimed to study on the practice of preventive guidelines and perception toward COVID-19 among Bangladeshi adults during the rapid rise of the outbreak. 
The study was based on the following hypotheses:

$\mathrm{H}_{01}$ : Socio-economic factors are significantly associated with good practice of following the guidelines recommended by WHO to avoid COVID-19.

$\mathrm{H}_{02}$ : Socio-economic factors are significantly associated with risk perception toward COVID-19.

\section{Methods}

Population: Bangladeshi adults were considered as a population in this cross-sectional study. A total number of 320 samples were selected from the population. This study was a part of our project "survey on psychological stress, practice and perception toward COVID-19 among Bangladeshi adults during the COVID-19 pandemic". Data was collected from 10 to 20 April, 2020 through online survey. Both sexes and most of the professions were considered, and participants were living in different locations in Bangladesh. The general characteristics and the project related information were collected from each of the subjects.

Sample size determination: The following formula was used to calculate our sample size $n=z^{2} p(1-p) / d^{2}$, where $\mathrm{n}$ is the number of samples, $\mathrm{z}$ is the value from the standard normal distribution for the selected confidence level (we considered $z=1.96$ for $95 \%$ confidence level), $p=$ the proportion of prevalence $=0.269$ (26.9\% was the perception for getting COVID-19), $1-p=0.731$, and $d=$ the margin of error $=0.05$ (considered). This information was taken from a published paper [14]. The mathematical formula delivered that 297 samples would be sufficient for our present study. However, we considered 320 samples for this study.

Questionnaire: All information were collected using a self-developed questionnaire, which was designed according to Survey Tool and Guidance (Rapid, simple, flexible behavioral insights on COVID-19) of WHO [15]. We prepared a draft questionnaire and sent it to three infectious disease specialists for their opinions on its simplicity and full content. We followed experts' suggestions, and finalized the questionnaire. The questionnaire was translated to Bangla (mother tongue of Bangladesh) to make it easily understandable for the participants. After translating, the questionnaire was carefully checked by our two authors for correctly fitting it to COVID-19 issues. We could not conduct pilot survey due to shortage of budget and time. However, the Cronbach Alpha value (0.792) showed that the internal consistency (reliability) of our questionnaire was more than the acceptance level (good).

Data collection procedure: Soft copies of the questionnaire were sent to the participants using online tools like e-mail, messenger, and WhatsApp in the personal computers, laptops, and cell phones. Four authors of the present study collected information, and the repetition of the responses was strictly checked. The questionnaire was sent to more than 400 Bangladeshi adults, out of whom 320 sent back filled up questionnaire with their written consent. The filled up questionnaires were checked by the present authors, and all questionnaires were valid. 
Inclusion criteria: For the prevailing locked down situation, we could not follow any criteria for the participants. However, the participants were known to the four authors and their colleagues, friends and relatives. We became sure that they were not suffering from any mental problems during the time of interview.

Measurement of practice to avoid and perception toward COVID-19: The practice of following WHO's guidelines to avoid COVID-19 was measured using a general question based on WHO-recommended guidelines [1]. We asked the participants, "Are you following COVID-19 prevention guidelines suggested by WHO?" The prevention guidelines were; (i) wash hands with soap frequently, (ii) wearing mask, (iii) maintain social distancing (>1 meter), (iv) avoid group gathering, (v) cover mouth and nose with a tissue or handkerchief when coughing or sneezing, and (vi) avoid touching the eyes, nose and mouth without washing hands with soap. Five measurement scales were used to understand the level of practice: (i) never, (ii) occasionally, (iii) sometimes, (iv) often, and (v) always. For further statistical analysis, samples were classified into two classes: (i) the participants answering "always" were considered as good practice (code, 1), and (ii) the participants answering other categorical scales (never to often), indicated as poor practice (code, 0$)$.

The risk of perception was measured by four types of perceptions toward COVID-19 such as (i) seriousness of the disease; question: how serious do you think COVID-19 is?, (ii) susceptibility to the disease; question: what do you think about your chance of getting COVID-19?, (iii) efficacy and selfefficacy; question: do you think that you will manage to carry out prevention measures currently recommended by the authority?, (iii) intention to carry out the measures; question: are you willing to carry out prevention measures currently recommended by the authority? Four categorical scales were used to determine the level of risk of perception such as for perception (i) (a) very serious, (b) serious, (c) slightly serious and (d) not serious; for perception (ii) (a) very much chance, (b) much chance, (c) slightly chance and (d) no chance; for perception type (iii) and (iv) (a) most certainly, (b) probably yes, (c) probably not and (d) certainly not. Then (a) and (b) were considered as risk perception (code, 1), and (c) and (d) were indicated as (ii) no risk perception (code, 0 ) for each type of perception. The total perception score ranged from 0 (no risk) to 4 (high risk). We added all scores of four types of perception ((i) to (iv)) for calculating the actual level of total scores for measuring high risk of perception. A cut off level of score $\leq 3$ (code, 0 ) was evaluated as low risk, and of score 4 (code, 1 ) was indicated as high risk.

Outcome variable: There were two outcome variables for this study: (i) nature of practice: (a) good practice (code, 1), and (b) poor practice (code, 0); (ii) risk of perception: (a) high risk perception (code, 1), and (b) low risk perception (code, 0 ).

Independent variables: Some socio-economic and demographic factors were considered as independent variables for finding association with good practice to avoid and high risk of perception toward COVID-19 among Bangladeshi adults. Most of the socioeconomic and demographic factors were selected on the basis of a related study [16]. These variables, their categories, codes, and definition are mentioned in Table 1. 
Table 1: Variables and their categories with codes and definition

\begin{tabular}{|c|c|c|c|c|c|c|c|}
\hline Variable & Group & Definition & Code & Variable & Group & Definition & Code \\
\hline \multirow[t]{2}{*}{ Gender } & Male & & 1 & Residence & Urban & & 1 \\
\hline & Female & & 2 & & Rural & & 2 \\
\hline \multirow[t]{2}{*}{$\begin{array}{l}\text { Marital } \\
\text { status }\end{array}$} & $\begin{array}{l}\text { Currently } \\
\text { married }\end{array}$ & & 1 & Age group (year) & $<40$ & $\begin{array}{l}\text { Young } \\
\text { adult }\end{array}$ & 1 \\
\hline & Unmarried & & 2 & & $\geq 40$ & Adult & 2 \\
\hline \multirow[t]{4}{*}{$\begin{array}{l}\text { Education } \\
\text { level }\end{array}$} & $\begin{array}{l}\text { Uneducated or } \\
\text { primary }\end{array}$ & & 1 & Occupation & $\begin{array}{l}\text { Service } \\
\text { holder }\end{array}$ & & 1 \\
\hline & Secondary & & 2 & & Student & & 2 \\
\hline & Higher & & 3 & & Housewife & & 3 \\
\hline & & & & & Others & & 4 \\
\hline \multirow[t]{2}{*}{$\begin{array}{l}\text { Family } \\
\text { member }\end{array}$} & $\leq 4$ & $\begin{array}{l}\text { Small } \\
\text { family }\end{array}$ & 1 & $\begin{array}{l}\text { Family monthly } \\
\text { income (Taka) }\end{array}$ & $\leq 15000$ & Poor & 1 \\
\hline & $\geq 5$ & $\begin{array}{l}\text { Large } \\
\text { family }\end{array}$ & 2 & & $\begin{array}{l}15001- \\
30000\end{array}$ & $\begin{array}{l}\text { Lower } \\
\text { middle }\end{array}$ & 2 \\
\hline \multirow[t]{2}{*}{$\begin{array}{l}\text { Type of } \\
\text { family }\end{array}$} & Nuclear & & 1 & & $\begin{array}{l}30001- \\
45000\end{array}$ & $\begin{array}{l}\text { Upper } \\
\text { middle }\end{array}$ & 3 \\
\hline & Joint & & 2 & & $>45000$ & Rich & 4 \\
\hline
\end{tabular}

Statistical analysis: Frequency distribution was used to determine the frequency with percentage of samples corresponding to each question and level. Chi-square $\left(\chi^{2}\right)$ test was utilized to find the association between (i) nature of practice and independent variables; (ii) risk of perception and independent variables. Binary logistic regression model was applied to examine the effect of socioeconomic and demographic factors on (i) nature of practice and (ii) risk of perception. Only significantly $(p<0.05)$ associated factors provided by $\chi^{2}$-test were used in logistic model as independent variables.

The underlying binary logistic regression model corresponding to variable is:

$y=\log [p /(1-p)]=\beta_{0}+\beta_{i} x_{j}+e_{i j}$

where, $p=$ the probability of good practice $(\operatorname{coded} 1)$, or high risk of perception (coded 1$), 1-p=$ the probability of poor practice (coded 0 ), or low risk of perception (coded 0 ), $\beta_{0}=$ intercept term, $\beta_{i}=$ unknown logistic regression coefficients, and $x_{j}=$ independent variable, and $e_{i j=}$ the error term. The parameter $\beta_{i}$ refers to the effect of $x_{j}$ on the log odds such that $y=1$.

Statistical analyses were carried out using SPSS (IBM Version 22.0). Statistical significance was accepted at $p<0.05$.

\section{Results}

Baseline characteristics: A total number of 320 samples were considered for this study to survey practice to avoid and perception toward COVID-19 among Bangladeshi adults. The mean and median age of 
sample was $40.99 \pm 14.99$ years ( $95 \% \mathrm{Cl}: 39.34-42.64)$ and 42.00 years respectively. The male and female samples were $64.4 \%$ and $35.6 \%$ and $60.0 \%$ and $40.0 \%$ of the participants came from urban and rural environment respectively. Of the samples, $72.5 \%$ was currently married, $44.1 \%$ was young adults (age $<40$ years), and $60 \%$ was high educated. More than $78 \%$ of the participants were living in nuclear families and $53.4 \%$ of the families was small (family member $\leq 4$ ). More than $22 \%$ of the respondents were living in rich families (family monthly income $>45000$ Taka) while $29.4 \%$ living in poor families (income $\leq 15000$ Taka), and $32.8 \%$ of the participants were service holder (Table 2).

Table 2: Association between practice and different characteristics of participants

\begin{tabular}{|c|c|c|c|}
\hline & & $\begin{array}{l}\text { Are you properly following the guidelines } \\
\text { recommended by WHO to avoid COVID-19? }\end{array}$ & \\
\hline Variable & Group, N (\%) & Yes & p-value \\
\hline \multirow[t]{2}{*}{ Gender } & Male, 206 (64.40) & $147(71.4)$ & 0.954 \\
\hline & Female, 114 (35.60) & $81(71.1)$ & \\
\hline \multirow[t]{2}{*}{ Residence } & Urban, 192 (60.00) & $151(78.6)$ & $\mathrm{p}<0.001$ \\
\hline & Rural,128 (40.00) & $77(60.2)$ & \\
\hline \multirow[t]{2}{*}{ Marital status } & $\begin{array}{l}\text { Currently married, } 232 \\
\text { (72.50) }\end{array}$ & $163(70.3)$ & 0.525 \\
\hline & Unmarried, 88 (27.50) & $65(73.9)$ & \\
\hline \multirow[t]{2}{*}{ Age group (year) } & $\begin{array}{l}\text { Young adult (age }>40) \text {, } \\
141(44.1)\end{array}$ & $105(74.5)$ & 0.259 \\
\hline & $\begin{array}{l}\text { Adult (age } \geq 40), 179 \\
(55.9)\end{array}$ & $123(68.7)$ & \\
\hline \multirow[t]{3}{*}{ Education level } & $\begin{array}{l}\text { Uneducated or primary, } \\
53 \text { (16.6) }\end{array}$ & $26(49.1)$ & $\mathrm{p}<0.001$ \\
\hline & Secondary, 73 (22.8) & $52(71.2)$ & \\
\hline & Higher, 194 (60.6) & $150(77.3)$ & \\
\hline \multirow[t]{2}{*}{ Family member } & Small ( $\leq 4), 171(53.40)$ & $114(66.7)$ & 0.052 \\
\hline & Large $(\geq 5), 149(46.60)$ & $114(76.5)$ & \\
\hline \multirow[t]{4}{*}{$\begin{array}{l}\text { Family monthly } \\
\text { income (Taka) }\end{array}$} & $\begin{array}{l}\text { Poor }(\leq 15000), 94 \\
(29.4)\end{array}$ & $55(58.5)$ & 0.008 \\
\hline & $\begin{array}{l}\text { Lower middle (15001- } \\
30000), 125(39.1)\end{array}$ & $92(73.6)$ & \\
\hline & $\begin{array}{l}\text { Upper middle ( } 30001- \\
45000), 28 \text { ( } 8.8)\end{array}$ & $22(78.6)$ & \\
\hline & $\begin{array}{l}\text { Rich }(>45000), 73 \\
(22.8)\end{array}$ & $59(80.8)$ & \\
\hline \multirow[t]{4}{*}{ Occupation } & $\begin{array}{l}\text { Service holder, } 105 \\
(32.80)\end{array}$ & $79(75.2)$ & 0.501 \\
\hline & Student, 66 (20.60) & $49(74.2)$ & \\
\hline & Housewife, 63 (19.70) & $42(66.7)$ & \\
\hline & Others, 86 (26.90) & $58(67.4)$ & \\
\hline \multirow[t]{2}{*}{ Type of family } & Nuclear, 250 (78.10) & $169(67.6)$ & 0.006 \\
\hline & Joint, $70(21.90)$ & $59(84.3)$ & \\
\hline
\end{tabular}

Practice to avoid COVID-19: It was noted that $71.3 \%$ of the participants followed always the guidelines of WHO to prevent COVID-19 (Figure). 
Chi-square test demonstrated that type of residence $(p<0.01)$, education level $(p<0.01)$, family's monthly income $(p<0.01)$, type of family $(p<0.01)$, and family member $(p=0.052)$ were significantly associated with practice to avoid COVID-19 (Table 2).

The logistic model exhibited that urban people had a 2.439-fold higher good practice than rural people $(\mathrm{OR}=2.439,95 \% \mathrm{Cl}: 1.488-3.999 ; \mathrm{p}<0.01)$. Good practice was decreased by $71.8 \%$ among uneducated or primary educated people compared to higher educated people (OR=0.282, 95\% $\mathrm{Cl}: 0.150-0.533 ; \mathrm{p}<0.01)$. Poor participants were less likely to follow WHO's guideline properly (good practice) than rich adults $(\mathrm{OR}=0.335,95 \% \mathrm{Cl}: 0.164-0.682 ; \mathrm{p}<0.01)$. Adults living in small (OR=0.614, 95\% Cl: 0.374-1.007; $p=0.053)$ and nuclear families (OR=0.389, 95\% Cl: 0.194-0.780; $p<0.01)$ were less likely to have good practice to avoid COVID-19 than joint and large family respectively (Table 6).

Perception toward COVID-19: It was found that 71.6\% and 23.8\% participants believed that COVID-19 was a very serious and serious disease respectively. Only $9.7 \%$ believed they had very much chance to get COVID-19 while $31.6 \%, 45.6 \%$ and $13.1 \%$ supposed to have much chance, slight chance and no chance to get this disease. More than $50 \%$ of the participants would be able to manage to carry out prevention measures recommended by the authority. More than $75 \%$ people were willing to carry out prevention measures currently recommended by the authority (Table 3).

Table 3: Perception of participants toward COVID-19

\begin{tabular}{|c|c|c|c|c|c|}
\hline Type of perception & Questions & & & & \\
\hline $\begin{array}{l}\text { Perception of } \\
\text { seriousness of the } \\
\text { disease }\end{array}$ & How serious do you think COVID-19 is? & $\begin{array}{l}\text { Very } \\
\text { serious, } \\
229 \\
(71.6)\end{array}$ & $\begin{array}{l}\text { Serious, } \\
76(23.8)\end{array}$ & $\begin{array}{l}\text { Slightly } \\
\text { serious, } \\
15(4.7)\end{array}$ & $\begin{array}{l}\text { Not } \\
\text { serious, } \\
0(0.0)\end{array}$ \\
\hline \multirow[t]{2}{*}{$\begin{array}{l}\text { Perception of } \\
\text { susceptibility to the } \\
\text { disease }\end{array}$} & $\begin{array}{l}\text { What do you think about your chance of } \\
\text { getting COVID-19? }\end{array}$ & $\begin{array}{l}\text { Very } \\
\text { much } \\
\text { chance, } \\
31(9.7)\end{array}$ & $\begin{array}{l}\text { Much } \\
\text { chance, } \\
101 \\
(31.6)\end{array}$ & $\begin{array}{l}\text { Slight } \\
\text { chance, } \\
146 \\
(45.6)\end{array}$ & $\begin{array}{l}\text { No } \\
\text { chance, } \\
42 \\
(13.1)\end{array}$ \\
\hline & & $\begin{array}{l}\text { Most } \\
\text { certainly }\end{array}$ & $\begin{array}{l}\text { Probably } \\
\text { yes }\end{array}$ & $\begin{array}{l}\text { Probably } \\
\text { not }\end{array}$ & $\begin{array}{l}\text { Certainly } \\
\text { not }\end{array}$ \\
\hline $\begin{array}{l}\text { Perception of } \\
\text { efficacy and self- } \\
\text { efficacy }\end{array}$ & $\begin{array}{l}\text { Do you think that you will manage to carry } \\
\text { out prevention measures currently } \\
\text { recommended by the authority? }\end{array}$ & $\begin{array}{l}48 \\
(15.0)\end{array}$ & $\begin{array}{l}182 \\
(56.9)\end{array}$ & $76(23.8)$ & $14(4.4)$ \\
\hline $\begin{array}{l}\text { Perception/Intention } \\
\text { to carry out the } \\
\text { measures }\end{array}$ & $\begin{array}{l}\text { Are you willing to carry out prevention } \\
\text { measures currently recommended by the } \\
\text { authority? }\end{array}$ & $\begin{array}{l}243 \\
(75.9)\end{array}$ & $\begin{array}{l}65 \\
(20.3)\end{array}$ & $12(3.8)$ & \\
\hline
\end{tabular}

The average risk of perception among participants was 3.05 \pm 0.75 (median, 3.00) (9\%\% Cl of mean: 2.963.13). The highest number of participants (51.6\%) provided 3 risk perceptions followed by all risk (4) (27.8\%), 2 risk (18.4\%), 1 risk (1.9\%) and no risk (0.3\%) respectively (Table 4$).$

Table 4: Level of risk of perception 


\begin{tabular}{llll}
\hline Mean $\pm \mathrm{SD}=3.05 \pm 0.75$ & Median $=3.00$ & \multicolumn{2}{l}{ 95\% CI of mean: 2.96-3.13 } \\
\hline Number of questions & Risk of perception, N (\%) & Number of questions & $\begin{array}{l}\text { Risk of perception, } \\
\text { N (\%) }\end{array}$ \\
\hline 0 & $1(0.3)$ & 3 & $165(51.6)$ \\
1 & $6(1.9)$ & 4 & $89(27.8)$ \\
2 & $59(18.4)$ & & \\
\hline
\end{tabular}

Chi-square test showed that gender $(p<0.05)$, age group (year) $(p<0.05)$, education level $(p<0.05)$, family monthly income (Taka) $(p<0.01)$ and occupation $(p<0.01)$ were significantly associated factors of high risk of perception among Bangladeshi people (Table 5).

Table 5: Association between perception toward COVID-19 and different characteristics of participants

\begin{tabular}{|c|c|c|c|c|}
\hline \multirow[b]{2}{*}{ Variable } & \multirow[b]{2}{*}{ Group } & \multicolumn{3}{|c|}{ Perception toward COVID-19 } \\
\hline & & Low risk & High risk & $\mathrm{p}$-value \\
\hline \multirow[t]{2}{*}{ Gender } & Male & $141(68.4)$ & $65(31.6)$ & 0.045 \\
\hline & Female & $90(78.9)$ & $24(21.1)$ & \\
\hline \multirow[t]{2}{*}{ Residence } & Urban & $134(69.8)$ & $58(30.2)$ & 0.241 \\
\hline & Rural & $97(75.8)$ & $31(24.2)$ & \\
\hline \multirow[t]{2}{*}{ Marital status } & Currently married & $172(74.1)$ & $60(25.9)$ & 0.206 \\
\hline & Unmarried & $59(67.0)$ & $29(33.0)$ & \\
\hline \multirow[t]{2}{*}{ Age group (year) } & Young adult (>40) & $93(66.0)$ & $48(34.0)$ & 0.027 \\
\hline & Adult $(\geq 40)$ & $138(77.1)$ & $41(22.9)$ & \\
\hline \multirow[t]{3}{*}{ Education level } & Uneducated or primary & $46(86.8)$ & $7(13.2)$ & 0.034 \\
\hline & Secondary & $50(68.5)$ & $23(31.5)$ & \\
\hline & Higher & $135(69.6)$ & $59(30.4)$ & \\
\hline \multirow{2}{*}{ Family member } & Small $(\leq 4)$ & $123(71.9)$ & $48(28.1)$ & 0.912 \\
\hline & Large $(\geq 5)$ & $108(72.5)$ & $41(27.5)$ & \\
\hline \multirow[t]{4}{*}{ Family monthly income (Taka) } & Poor $(\leq 15000)$ & $80(85.1)$ & $14(14.9)$ & 0.004 \\
\hline & Lower middle (15001-30000) & $87(69.6)$ & $38(30.4)$ & \\
\hline & Upper middle (30001-45000) & $20(71.4)$ & $8(28.6)$ & \\
\hline & $\operatorname{Rich}(>45000)$ & $44(60.3)$ & $29(39.7)$ & \\
\hline \multirow[t]{4}{*}{ Occupation } & Service holder & $69(65.7)$ & $36(34.3)$ & 0.003 \\
\hline & Student & $40(60.6)$ & $26(39.4)$ & \\
\hline & Housewife & $53(84.1)$ & $10(15.9)$ & \\
\hline & Others & $69(80.2)$ & $17(19.8)$ & \\
\hline \multirow[t]{2}{*}{ Type of family } & Nuclear & $183(73.2)$ & $67(26.8)$ & 0.445 \\
\hline & Joint & $48(68.6)$ & $22(31.4)$ & \\
\hline
\end{tabular}

The effect of socio-economic and demographic factors on high risk of perception was described in Table 6. The statistical model demonstrated that males had 1.729-fold higher risk than females for perception toward COVID-19 (OR=1.729, 95\% Cl: 1.01-2.96; $p<0.05)$, and the high risk was diminished by $65.2 \%$ among lower educated (no or primary) adults compared to higher educated ( $\mathrm{OR}=0.348,95 \% \mathrm{Cl}$ : 0.149 $0.816 ; p<0.05)$. High risk of perception was decreased by $73.4 \%$ among poor people compared to rich people in Bangladesh (OR= 0.266, 95\% Cl: 0.127-0.554; $p<0.01)$. Housewife (OR=0.362, 95\% Cl: 0.165$0.794 ; p<0.05)$ and other professionals $(\mathrm{OR}=0.472,95 \% \mathrm{Cl}: 0.243-0.919 ; \mathrm{p}<0.05)$ had low risk of perception toward COVID-19 than service holders respectively. Also, it was found that high risk of 
perception of young adults were 1.737 times higher than that of people aged $\geq 40$ years $(0 R=1.737,95 \%$ Cl: 1.061-2.844; p<0.05) (Table 6).

Table 6: Effect of socio-economic and demographic factors on practice to avoid and perception toward COVID-19 among Bangladeshi adults

\begin{tabular}{|c|c|c|c|c|c|}
\hline \multicolumn{3}{|l|}{ Practice } & \multicolumn{3}{|l|}{ Perception } \\
\hline Covariates & $\begin{array}{l}\text { OR (95\% CI for } \\
\text { OR) }\end{array}$ & p-value & Covariates & $\begin{array}{l}\text { OR (95\%CI for } \\
\text { OR) }\end{array}$ & $\mathrm{p}$-value \\
\hline Residence & & & Gender & & \\
\hline Urban Vs Rural & $\begin{array}{l}2.439(1.488- \\
3.999)\end{array}$ & $\mathrm{p}<0.001$ & Male Vs Female & $1.729(1.01-2.96)$ & 0.046 \\
\hline Education Level & & & Education Level & & \\
\hline $\begin{array}{l}\text { Uneducated or Primary } \\
\text { Vs Higher }\end{array}$ & $\begin{array}{l}0.282(0.150- \\
0.533)\end{array}$ & $\mathrm{p}<0.001$ & $\begin{array}{l}\text { Uneducated or Primary } \\
\text { Vs Higher }\end{array}$ & $\begin{array}{l}0.348(0.149- \\
0.816)\end{array}$ & 0.015 \\
\hline Secondary Vs Higher & $\begin{array}{l}0.726(0.395- \\
1.334)\end{array}$ & 0.303 & Secondary Vs Higher & $\begin{array}{l}1.053(0.589- \\
1.882)\end{array}$ & 0.863 \\
\hline $\begin{array}{l}\text { Family Monthly Income } \\
\text { (Taka) }\end{array}$ & & & $\begin{array}{l}\text { Family Monthly Income } \\
\text { (Taka) }\end{array}$ & & \\
\hline Poor Vs Rich & $\begin{array}{l}0.335(0.164- \\
0.682)\end{array}$ & 0.003 & Poor Vs Rich & $0.266(.127-.554)$ & $\mathrm{p}<0.001$ \\
\hline Lower middle Vs Rich & $\begin{array}{l}0.662(0.327- \\
1.339)\end{array}$ & 0.251 & Lower middle Vs Rich & $\begin{array}{l}0.663(.362- \\
1.213)\end{array}$ & 0.182 \\
\hline Upper middle Vs Rich & $\begin{array}{l}0.870(0.297- \\
2.548)\end{array}$ & 0.800 & Upper middle Vs Rich & $\begin{array}{l}0.607(0.236- \\
1.561)\end{array}$ & 0.300 \\
\hline Family member & & & Occupation & & \\
\hline $\begin{array}{l}\text { Small family Vs Large } \\
\text { family }\end{array}$ & $\begin{array}{l}0.614(0.374- \\
1.007)\end{array}$ & 0.053 & $\begin{array}{l}\text { Student Vs Service } \\
\text { holder }\end{array}$ & $\begin{array}{l}1.246(0.659- \\
2.356)\end{array}$ & 0.499 \\
\hline Type of family & & & $\begin{array}{l}\text { Housewife Vs Service } \\
\text { holder }\end{array}$ & $\begin{array}{l}0.362(0.165- \\
0.794)\end{array}$ & 0.011 \\
\hline \multirow[t]{2}{*}{ Nuclear Vs Joint } & $\begin{array}{l}0.389(0.194- \\
0.780)\end{array}$ & 0.008 & $\begin{array}{l}\text { Others Vs Service } \\
\text { holder } \\
\text { Age Group }\end{array}$ & $\begin{array}{l}0.472(0.243- \\
0.919)\end{array}$ & 0.027 \\
\hline & & & Young adults Vs Adults & $\begin{array}{l}1.737(1.061- \\
2.844)\end{array}$ & 0.028 \\
\hline
\end{tabular}

\section{Discussion}

COVID-19 has become a hot topic of discussion in all kinds of media and among people across the world. Though the facts about the causation, transmission, control, treatment and prevention of the disease are the same, perceptions and practices toward it are varied due to difference in levels of socioeconomic status and demographic background, and measures taken by the governments. This demands specific studies for specific population. Being the first of its kind in Bangladesh, our study laid down the founding stone in this area of research.

We found that majority of the participants (71.3\%) are practicing the guidelines of WHO to prevent COVID19. Zhong et al (2020) also reported that the majority of the Chinese residents (about 98\%) had appropriate practice of measures for prevention of COVID-19 [17]. Another study observed a higher rate of practice (over 90\%) among the US people [18]. High education, living in urban location, and high income, 
the most contributory factors for good practice among Bangladeshi people are inter-related. These people are more knowledgeable, more sincere, and more conscious about health. This might help increase their practice of following the preventive measures of WHO. Larger family is also helpful in acquiring knowledge and doing practice. The Chinese people with high socioeconomic status were found to have a higher percentage of good practice $[17,18]$. We analyzed the individual types of the perception of participants toward COVID-19 such as the seriousness of the disease, susceptibility of the disease, selfefficacy and intention to carry out the measures to prevent the disease and identified that some socioeconomic and demographic factors were associated with these perceptions. Our study revealed that the overall risk perception toward COVID-19 among the Bangladeshi general people was more or less positive but not of expected level. Almost similar finding was found in another study conducted in Bangladesh [13]. The high risk of perception of younger adults, males, high educated people, rich ones, and service holders might be explained on the basis of a hypothesis that these people usually follow personal hygiene at a higher rate than others. Most of the participants (71.6\%) were knowledgeable about the seriousness of the disease; more than $50 \%$ and $75 \%$ thought they had the capacity and will of continuing preventive measures respectively. Only $9.7 \%$ feared of getting the infection certainly. All these findings reveal that the overall conception and attitude of the respondents was positive that would help them prevent COVID-19.

However, the present study had several limitations that should be considered when interpreting the results. Firstly, the sample size was small that cannot represent the whole Bangladeshi population and the changes in practice and perception of COVID-19 could not be generalized. A larger-scale study that includes more participants from all the regions in the country is needed to provide greater statistical reliability. Secondly, this is a cross-sectional study based on online survey in a short period of time and the data was collected through self-reported perceptions and practices related to COVID-19 questionnaire. It is partly dependent on the participants' honesty and recalls ability; thus, they may be subject to recall bias. Thirdly, the duration of the study was short, during a certain point of the peak of the outbreak. The changes in practice and perception could not be monitored. Fourthly, the family monthly income $\leq 15000$ (Taka) group population was not explored enough. The low-income population might be uneducated or have low education level due to low socioeconomic background and this might change the practice and perception toward COVID-19 practice and perception. The socioeconomic factors are significantly associated with practice and perception in this study. Fifthly, due to online survey, the vulnerable populations such as older adults, adults with comorbid conditions, rural, and working people at the grassroot level could have not taken part in the survey although they are more likely to have poor knowledge and perception, negative attitudes, and inappropriate preventive practices towards COVID-19.

\section{Conclusions And Recommendations}

In summary, our study revealed that the Bangladeshi population with a high socioeconomic status has good knowledge, optimistic attitude, and appropriate practices towards the prevention of COVID-19 during the peak time of the pandemic outbreak. In addition, good COVID-19 perception will influence the practices towards COVID-19, suggesting that proper health education programs are urgently needed to 
improve COVID-19 knowledge and helpful for encouraging optimistic attitudes and maintaining safe practices especially among the most vulnerable groups such as uneducated or less educated, aged, rural and poor people. In the face of the aggravating situation of the COVID-19 pandemic in Bangladesh, the government and non-government stakeholders should pay attention to the vulnerable groups for controlling and preventing the infection. More studies are also warranted for investigating the knowledge, perception and practice towards COVID-19 among the Bangladeshi population of low socioeconomic status.

\section{Abbreviations}

2019nCoV: 2019 Novel Coronavirus; Cl: Confidence Interval; COVID-19: Coronavirus Disease 2019; IBM: International Business Machines; OR: Odds Ratio; SARS: Severe Acute Respiratory Syndrome; SPSS: Statistical Package for the Social Sciences; WHO: World Health Organization

\section{Declarations}

Ethics approval and consent to participate: We received ethical clearance from the Ethical Committee, Institute of Biological Sciences (IBSc), Rajshahi University, Rajshahi-6205, Bangladesh to study on infectious diseases. The written consent of every participant was taken and they sent it to us with filled up questionnaire.

Consent for publication: Not applicable for this study.

Availability of data and material: Data will be available on request.

Competing interests: The authors have no conflict of interests.

Funding: There was no grant, technical or corporate support for this study.

Authors Contributions: MAW, MGH and LLL conceptualized and designed the study. MAW, MGH, MMH and ASMM collected data. MAW, MGH, MMH, LLL and SM interpreted data and findings. MAW, MGH and LLL wrote the manuscript. All authors reviewed and approved the manuscript.

Acknowledgement: We are indebted to those of our colleagues, friends, and relatives who helped us select and contact the respondents. We are also thankful to the respondents who took part in our survey.

\section{References}

1. WHO (2020a) Corona Virus. https://www.who.int/health-topics/coronavirus\#tab=tab_1. Accessed 27 March, 2020.

2. Bhagavathula AS, Aldhaleei WA, Rahmani J, Mahabadi MA, Bandari DK. Novel Coronavirus (COVID19) Knowledge and Perceptions: A Survey on Healthcare workers. Preprint at https://www.medrxiv.org/content/10.1101/2020.03.09.20033381v2 
3. World Health Organization. Novel Coronavirus (2019-nCoV): situation report, 13 (PDF) (Report). 2020. https://experience.arcgis.com/experience/685d0ace521648f8a5beeeee1b9125cd. Accessed 13 March 2020.

4. CDC (Centers for Disease Control and Prevention). Coronavirus Disease 2019 (COVID-19), Symptoms of Coronavirus. 2020. https://www.cdc.gov/coronavirus/2019-ncov/symptomstesting/symptoms.html. Accessed 3 May 2020.

5. Novel Coronavirus (2019nCoV), Situation Report-1, 21 January 2020. https://www.who.int/docs/default-source/coronaviruse/situation-reports/20200121-sitrep-1-2019ncov.pdf?sfvrsn=20a99c10_4. Accessed 3 May 2020.

6. Statement on the second meeting of the International Health Regulations (2005) Emergency Committee regarding the outbreak of novel coronavirus (2019-nCoV). 2020. https://www.who.int/news-room/detail/30-01-2020-statement-on-the-second-meeting-of-theinternational-health-regulations-(2005)-emergency-committee-regarding-the-outbreak-of-novelcoronavirus-(2019-ncov). Accessed 3 May 2020.

7. WHO Director-General's opening remarks at the media briefing on COVID-19-11 March 2020. 2020. https://www.who.int/dg/speeches/detail/who-director-general-s-opening-remarks-at-the-mediabriefing-on-covid-19--11-march-2020. Accessed 3 May 2020.

8. CVRC (Corona Virus Resource Centre), John Hopkins University and Medicine. COVID-19 Dashboard by the Center for Systems Science and Engineering (CSSE) at Johns Hopkins University (JHU). 2020. https://coronavirus.jhu.edu/map.html. Accessed May 82020.

9. Person B, Sy F, Holton K, Govert B, Liang A. National Center for Infectious Diseases SCOT. Fear and stigma: the epidemic within the SARS outbreak. Emerg Infect Dis. 2004; 10: 358-63.

10. Tao N. An analysis on reasons of SARS-induced psychological panic among students. Journal of Anhui Institute of Education. 2003; 21: 78-9.

11. IEDCR (Institute of Epidemiology, Disease Control and Research). Covid-19 Status Bangladesh. https://www.iedcr.gov.bd/. Accessed 8 May 2020.

12. Wadood MA, Mamun ASMA, Rafi MA, Islam MK, Suhaili M, Lai LL, Hossain MG. Knowledge, attitude, practice and perception regarding COVID-19 among students in Bangladesh: Survey in Rajshahi University. Preprint at medRxiv preprint. Doi: https://doi.org/10.1101/2020.04.21.20074757

13. Farhana KM, Mannan KA. Knowledge and perception towards Novel Coronavirus (COVID 19) in Bangladesh. International Research Journal of Business and Social Science. 2020; 6(2): 76-79.

14. Shabu S, Amen KM, Mahmood KI, Shabila NP. Risk perception and behavioral response to COVID-19 in Iraqi Kurdistan Region. BMC Infectious Diseases Pre-print at DOI: 10.21203/rs.3.rs-22025/v1

15. Survey Tool and Guidance (Rapid, simple, flexible behavioural insights on COVID-19). 2020. http://www.euro.who.int/_data/assets/pdf_file/0007/436705/COVID-19-survey-tool-andguidance.pdf?ua=1. Accessed 3 May 2020.

16. Huynh Data for understanding the risk perception of COVID-19 from Vietnamese sample. Data Brief. 2020; 30: 105530. doi: 10.1016/j.dib.2020.105530 
17. Zhong BL, Luo W, Li HM, Zhang QQ, Liu XG, Li WT, Li Y. Knowledge, attitudes, and practices towards COVID-19 among Chinese residents during the rapid rise period of the COVID-19 outbreak: a quick online cross-sectional survey. International Journal of Biological Sciences. 2020;16(10), 1745.

18. McFadden SM, Malik AA, Aguolu OG, Willebrand KS, Omer SB. Perceptions of the adult US population regarding the novel coronavirus outbreak. PLoSONE. 2020; 15(4):e0231808. https://doi.org/10.1371/journal.pone.0231808.

\section{Figures}

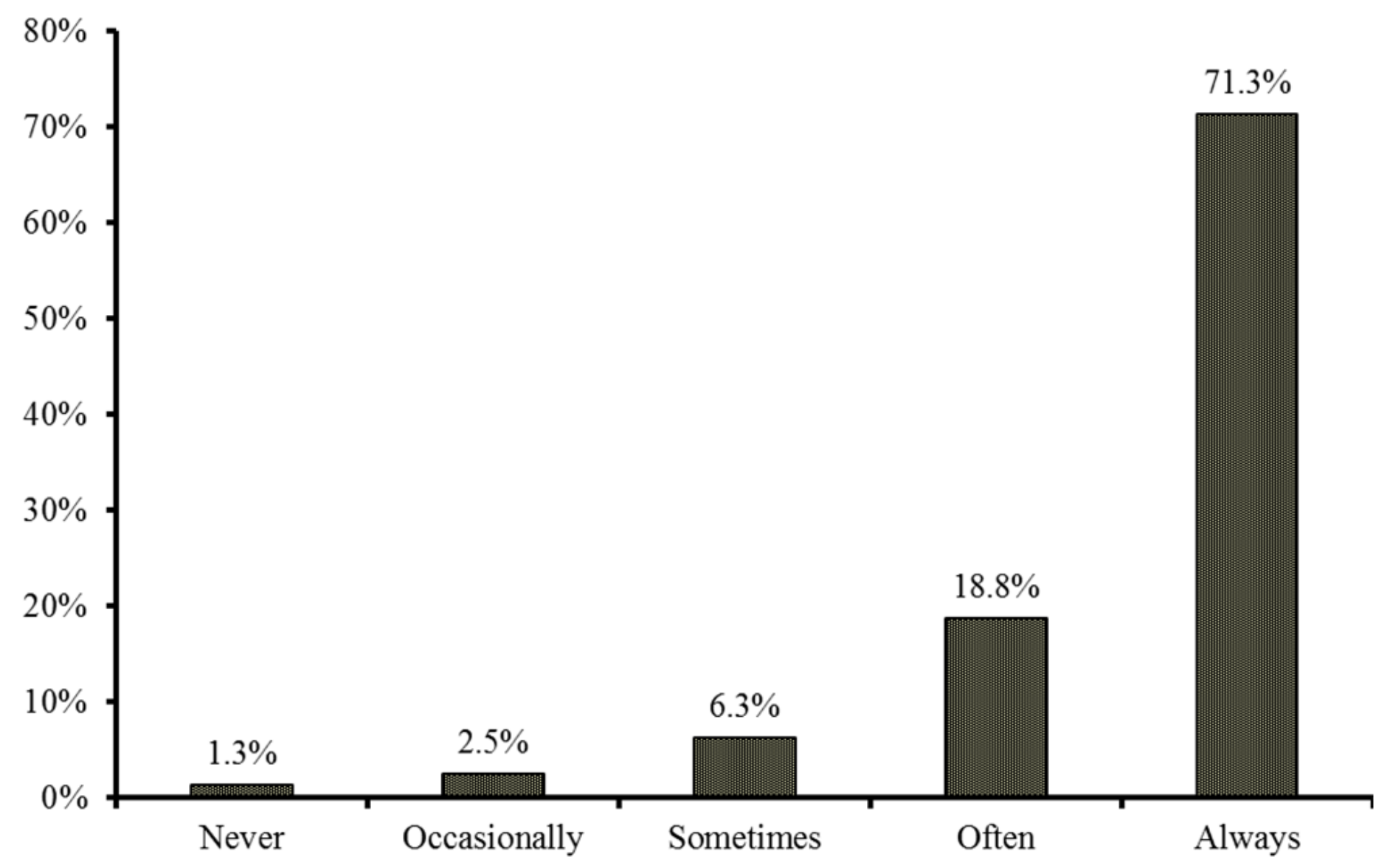

Figure 1

Level of practice to follow the guidelines recommended by WHO 